\title{
Agricultural Development in Zambia's Northern Province: Perspectives from the Field Level
}

\author{
Howard White, Jennifer Leavy and Venkatesh Seshamani*
}

\section{Introduction}

Along with the rest of the economy, per capita output in Zambia's agricultural sector has been in long-run decline. On a crop-by-crop basis the picture is more nuanced. The decline in maize production since maize market liberalisation in the early 1990s has been partly offset by increased production of other crops, but diversification into other crops has been geographically concentrated. Many farmers, especially in remote locations, have reverted to production of old staple crops rather than diversified into highvalue outputs. This article describes this situation from the point of view of Northern Province.

\section{The Zambian context}

At Independence in 1964, Zambia was a relatively prosperous country by sub-Saharan Africa standards, by virtue of its copper income. Following the copper price collapse in the mid-1970s, growth faltered and external debt began to grow, leaving the huge, politically difficult, challenge of adjusting the economy away from its copper dependence. By 1990 income per capita had fallen by almost onethird since Independence (Figure 1).

Reforms undertaken during the 1990s failed to revive the economy, with per capita income lower today than when liberalisation was embarked upon. The donor community points to weaknesses in implementation, especially in terms of pace and sequencing. However, the Zambian government has done what they were asked. The poor growth record can be attributed to the inappropriateness of some of the policies adopted, and the fact that reform was not financed since virtually all aid inflows have been consumed in external debt payments (White 1997: 56-87; White and Dijkstra 2003).

From Independence to 2003, agricultural value added increased by 125 per cent in real terms, less than the 190 per cent growth in population over the same period (Figure 1). Agricultural productivity has been stagnant across the period, varying mainly according to the weather (Zulu et al. 2000; IDL Group 2002). In consequence, daily energy supply (food availability from total food consumption, including both domestic production and imports including food aid) has fallen from the late 1970s, when it peaked at almost 2,400 kcals per person. By the start of the 1990s it had fallen to 1,900 per person, decreasing further still by the end of that decade. These figures are well below the levels required for adequate nutrition.

The story of worsening nutritional status in the 1990s is largely one of falling maize production, as this crop has typically provided about two-thirds of calorie intake. In 1989, Zambia produced 1.85 billion metric tons of maize, allowing 0.8 billion tons to be added to stocks and still have sufficient to provide 1,225 calories per person. But by 2001 production was only 0.6 billion tons, so that even after taking 0.6 billion from the country's maize reserve, only 1,023 calories per person were available from maize. This drop of 200 calories per person from maize availability accounts for the drop in daily energy supply between the two years (from 1,995 in 1989 to 1,895 in 2001, the gap being mainly filled by cassava, sugar and wheat). Between

IDS Bulletin Vol 36 No 2 June 2005 @ Institute of Development Studies 


\section{Figure 1: GDP, Agricultural Output and Calorie Supply Per Person in Zambia}

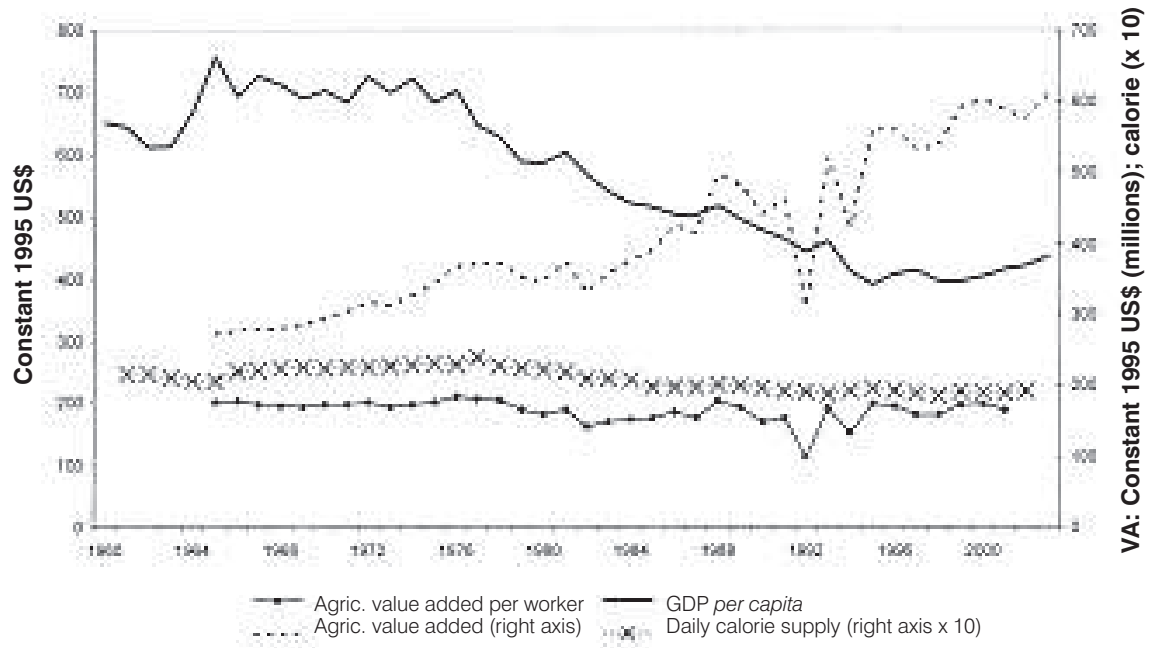

Sources: World Bank World Development Indicators and FAOSTAT (accessed 16 January 2005).

1992 and 2001 the proportion of stunted children (more than 2SDs below the height-for-age reference median) rose from 36 to 47 per cent. ${ }^{1}$

After growth in area and yield in the 1980s, maize production declined in the 1990s (Figure 2), mirroring changes in the market environment. In the 1980s the state marketing board provided subsidised inputs and purchased output at the same price from farmers throughout the country. ${ }^{2}$ Once this pan-territorial pricing system was dismantled,

\section{Figure 2: Maize Area, Production and Yield in Zambia}

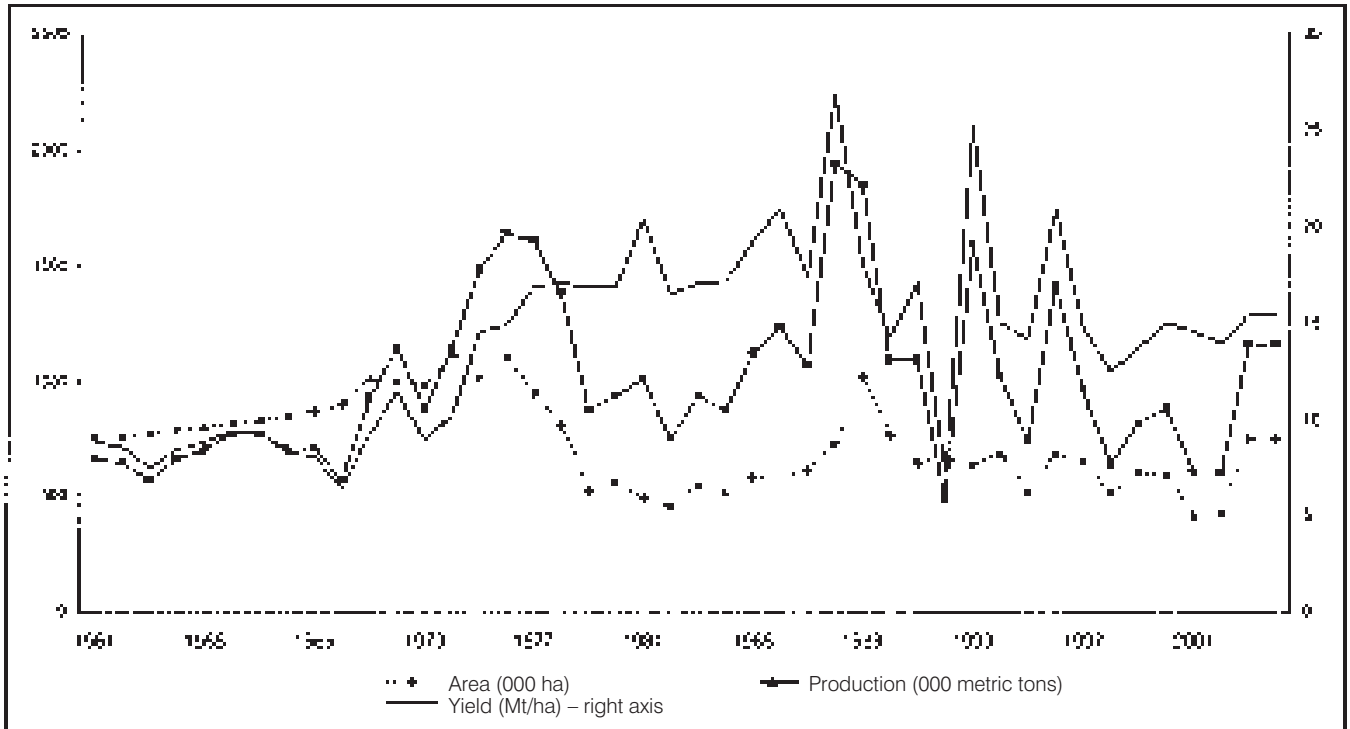

Source: FAOSTAT (accessed 16 January 2005). 
Table 1: Production and Export of Selected Crops ('000 metric tonnes)

\begin{tabular}{llllll}
\hline & $\mathbf{1 9 8 0 - 8 4}$ & $\mathbf{1 9 8 5 - 8 9}$ & $\mathbf{1 9 9 0 - 9 4}$ & $\mathbf{1 9 9 5 - 9 9}$ & $\mathbf{2 0 0 0 - 0 4}$ \\
\hline $\begin{array}{lllll}\text { Production } \\
\quad \text { Coffee }\end{array}$ & 82 & 711 & 1,605 & 2,217 & 5,168 \\
$\quad$ Tobacco & 3,247 & 3,615 & 4,992 & 4,464 & 4,660 \\
& & & & & \\
Exports & 2,760 & 4,585 & 1,713 & 11,950 & 13,810 \\
$\quad$ Cotton lint & 1,696 & 1,643 & 2,948 & 3,408 & 6,513 \\
$\quad$ Tobacco & & & & & \\
\hline
\end{tabular}

Source: FAOSTAT (accessed 16 January 2005).

farmers could no longer afford inputs and traders did not find it worthwhile to purchase from more remote producers. During the 1990s average fertiliser use per hectare of cropland fell by about two-thirds. Poorer farmers retreated into subsistence production of crops requiring fewer inputs, such as cassava. This situation has begun to change in the last two years, during which the government has reintroduced input subsidies, though access to these is uneven.

There have been some successes in Zambian agriculture following liberalisation. These include high-value crops such as paprika and cut flowers. However, production of such crops is geographically concentrated, affecting a tiny percentage of the agricultural workforce. Other cash crops have also experienced a revival, notably coffee, tobacco and cotton (Table 1 ; tobacco's revival is evident in export figures rather than production). Coffee and tobacco are grown on large-scale commercial farms, mainly in Eastern Province with a smaller share of production in Central and Southern provinces. Overall, the commercial farms have accounted for the bulk of the agricultural revival (IDL Group 2002). Most important for smallholders has been the revival of the cotton sector. Production and exports fell to an all-time low in 1994, the year before the parastatal LINTCO was privatised. During the second half of the 1990s, outgrower schemes brought up to 150,000 households - around 10 per cent of all rural households - into cotton production, with production and exports booming (Table 1; see also Tschirley et al. 2004). This experience illustrates the role that outgrower schemes, through which a large company provides supplier's credit for farmers to buy inputs and technical advice, can play in diversification. ${ }^{3}$

There is thus scope for debate whether the decline in maize production represents diversification into higher value crops, rather than farmers being pushed out of maize by falling returns (see Zulu et al. 2000). The answer varies by geographical area. The increased production of cash crops has been concentrated in Eastern, Central and Southern Provinces, where three-quarters of Zambia's large farms are located (Zulu et al. 2000). In Northern Province and Luapula, maize has mainly been replaced by cassava, and there is little evidence of diversification into grains and legumes. This experience in Northern Province is now examined in more detail.

\section{Agriculture in Northern Province 3.1 Overview}

Agriculture in Northern Province consists almost entirely of small-scale farming, with some coffee and sugar plantations, which have expanded since privatisation and are an important source of local employment.

The experience of the province over the last two decades is an extreme case of what has happened to agriculture in the country as a whole: a move into maize and out again, partly offset by geographically concentrated diversification. Policies to promote maize production in the 1980s had a large influence, so that by the end of the decade the province was a net exporter of maize to the more populous and urbanised Copperbelt and Lusaka. Moore and Vaughan (1994) describe this transition from citemene (slash-and-burn production, mostly of cassava) to ibala (fixed fields fed with fertiliser). The 1990s saw a reversal of this process, with maize 
Table 2: Index of Socio-economic Status by Community ${ }^{1}$

\begin{tabular}{lllll}
\hline & Kabila & Lufubu & Ngulula & All \\
\hline Mean & 0.21 & 0.33 & 0.43 & 0.33 \\
Median & 0.19 & 0.32 & 0.35 & 0.28 \\
Poor (bottom 40\%) & 78 & 30 & 19 & 40 \\
Gini coefficient & 0.20 & 0.19 & 0.28 & 0.27 \\
\hline
\end{tabular}

Notes: (1)The index of socio-economic status is an asset-based index of household wealth based on household survey data. It can take values between zero and one. Please contact the authors for details of how the index was constructed.

(2) Percentage of households in each community falling in the bottom $40 \%$.

production falling from 1.8 million $90 \mathrm{~kg}$ bags in 1988 to just 0.5 million, ten years later. During fieldwork, many farmers would tell how they used to grow maize but stopped doing so once fertiliser became unaffordable.

We turn now to the perspective from three rural communities that were the subject of fieldwork in 2002-03:

1. Ngulula: a village with an irrigation system, which produces vegetables for market, mainly in the provincial capital of Kasama $25 \mathrm{~km}$ away

2. Lufubu: a resettlement scheme over $200 \mathrm{~km}$ from Kasama and $37 \mathrm{~km}$ from the district headquarters, Luwingu

3. Kabila: a relatively remote community, $29 \mathrm{~km}$ from the main road on a poor quality feeder road, and $87 \mathrm{~km}$ in total from Kasama.

Ngulula is the most prosperous of the three, Kabila the least so (Table 2). Over three-quarters of the population of Kabila are poor, compared with just 19 per cent of those in Ngulula. However, differentiation (measured by the Gini coefficient of socio-economic status) is greater in Ngulula. Education levels are lowest in Kabila, but higher in Lufubu than Ngulula, with a high proportion of secondary graduates in the former, reflecting the urban background of many settlers. This pattern will change over time, since few children from Lufubu attend secondary school, for reasons of both distance (the nearest school going beyond Grade 4 is $9 \mathrm{~km}$ away) and cost (both the amount and the need to pay in cash, which is more than most households can raise).

\subsection{Production and exchange}

Cassava and millet are among the most commonly produced crops (Table 3). Millet is produced by well over half of all households and cassava by well over one-third. Maize production remains common; local varieties dominate although hybrid maize is grown

Table 3: Percentage of Households Producing Selected Crops by Community

\begin{tabular}{llllllll}
\hline & Kabila & Lufubu & Ngulula & & Kabila & Lufubu & Ngulula \\
\hline Local maize & 32 & 72 & 47 & Cabbages & 0 & 3 & 37 \\
Hybrid maize & 0 & 7 & 37 & Sunflowers & 5 & 28 & 19 \\
Cassava & 37 & 26 & 47 & Mangoes & 5 & 8 & 21 \\
Millet & 59 & 74 & 53 & Bananas & 0 & 23 & 33 \\
Sorghum & 12 & 8 & 35 & Squash & 15 & 23 & 14 \\
Mixed beans & 90 & 93 & 74 & Oranges & 5 & 0 & 7 \\
Soya beans & 2 & 18 & 35 & Tomatoes & 10 & 18 & 28 \\
Sweet potato & 41 & 54 & 79 & Irish potato & 0 & 7 & 9 \\
Groundnuts & 88 & 87 & 84 & Other crops & 5 & 16 & 7
\end{tabular}


Table 4: Percentage Share of Selected Crops Sold

\begin{tabular}{llll}
\hline & Kabila & Lufubu & Ngulula \\
\hline Local maize & 42 & 31 & 20 \\
Hybrid maize & n.a. & 40 & 26 \\
Cassava & 2 & 17 & 5 \\
Millet & 10 & 33 & 12 \\
Mixed beans & 60 & 74 & 47 \\
Soya beans & 0 & 33 & 65 \\
Sweet potatoes & 0 & 29 & 60 \\
lrish potatoes & n.a. & 59 & 97 \\
Groundnuts & 35 & 45 & 58 \\
Bananas (sweet) & n.a. & 27 & 72 \\
Tomatoes & 0 & 57 & 90 \\
Sunflowers & 0 & 100 & 100 \\
\hline
\end{tabular}

Note: n.a. indicates crop not produced in that community.

by more than one-third of households in Ngulula. Other widespread crops are sweet potato, mixed beans and groundnuts. Beans and groundnuts are important sources of protein, given that meat consumption is relatively rare, and provide a relatively high-value crop should there be a marketable surplus.

Farmers in Ngulula are engaged in a broader range of cropping activities. For example, cabbages and Irish potatoes are not grown at all in Kabila, though the former are grown by more than onethird of households in Ngulula. These crops are more likely to be grown in a 'garden' than a 'field', and more households in Ngulula have gardens, usually located along irrigation furrows. In Kabila, informants revealed that many people used to have gardens, where they grew tomatoes, rape, Chinese cabbage and cowpeas, but have given them up as a result of problems with water and the unaffordability of other inputs.

As a result of higher production and greater diversification, households in Ngulula are more likely to have marketable surplus. Table 4 shows the percentage of each crop sold. As expected a large proportion of high-value crops such as bananas and tomatoes are sold, and these are grown mostly in Ngulula. But households in all three communities market significant proportions of maize, mixed beans and groundnuts.

Market access is not a problem for farmers in Ngulula. It is near to Kasama, and people from nearby villages assemble at the Ngulula junction off the Kasama road to buy produce, so farmers face lower transport costs and avoid the food levy on produce going into Kasama market. Traders also come to Ngulula, as well as other markets, from other provinces (especially the Copperbelt and Lusaka) to buy produce. The distances to the junction are such that farmers can carry produce, though using a bicycle is more common. The main problem facing Ngulula farmers is the large seasonal variations in supply, and hence price, for various crops. Prices are highest during the rainy season (November-March) and during September and October.

By contrast, it is very difficult for farmers from Kabila and Lufubu to get their produce to market. Distances are considerable, infrastructure is poor and there is no reliable transport. It is a ten-hour walk from Lufubu to the nearest market (Luwingu), necessitating an overnight stay. Even by bicycle, it takes three or four hours. For farmers in Kabila, cycling to Kasama takes an average of 12 hours on the main road, and for some it takes considerable time to reach this road depending on which Section of Kabila they live in.

Hence, most households in Lufubu and Kabila sell their surplus to traders who visit the villages from time to time to buy produce, usually through barter for consumer goods (cooking oil, soap, salt, sugar or salaula-second-hand clothes). The implicit prices charged by traders for these goods can be anything from two to ten times the amount they paid for them. Traders are most likely to visit between April and July, when crop prices are lowest. Villagers have a strong sense that they are being cheated. A handful of farmers in Lufubu (eight in total) sell their produce on the Copperbelt, where prices are said to be much higher. They can afford to do this because the volume of their surplus is enough to warrant the transport outlay. They wait along the road for cars and take their produce to markets in the Copperbelt. Before returning, they buy inputs for other businesses or goods for trading back home. These better-off farmers also employ labour on their plots and all use fertiliser.

The result of this system of exchange is that economic life in rural communities is relatively 'unmonetised' (though 'de-monetised' may be more appropriate, as people say cash was common in the 1980s), Ngulula being an exception in this regard. Some money is needed for school and health fees and essential purchases from shops. Agricultural 
inputs may require cash, but can also be obtained in exchange for crops. Cash is most likely to be received from wage work, though some labour is carried out on a reciprocal basis, or payment may be in kind. For example, settlers in Lufubu may kill a goat or a pig when they have a piece of land cleared in order to pay workers. New settlers pay existing settlers salaula to help them clear land. Women more commonly use beer to pay workers who help them on their plots, especially for land preparation for citemene (cutting trees). The main sources of cash labour are private plantations. Young men regularly seek casual work there, and couples do so to raise cash to buy fertiliser.

\subsection{Constraints on agricultural production}

Many farmers say that they previously produced maize but have reverted to cassava as they cannot afford the fertiliser necessary for good maize yields. This survey took place after the government had made the new fertiliser subsidy available. Yet only one household interviewed in Kabila had used fertiliser in the previous season, compared with 40 per cent of households in Lufubu and 53 per cent in Ngulula. Hence, even with a subsidy, access to fertiliser remains constrained by poverty and poor infrastructure.

Roads are the most important part of infrastructure. Ngulula benefits from the high quality of its feeder road to the tarred road into Kasama. By contrast, the Kasama-Luwingu road used to be tarred, but is no longer. The other commonly mentioned aspect of economic infrastructure is irrigation (canals and furrows). Northern Province has high rainfall and many perennial rivers; it is less affected by the droughts, which afflict southern Zambia. While Ngulula is an example of a successful irrigation scheme that has been functioning since 1955, other schemes in the Province started during the 1970 s have fallen into disuse. Irrigation provision needs to be sustainable. Although there is a wellestablished tradition of communal labour in rural Zambian communities, this cannot be readily called upon for schemes which have unequal benefits, as irrigation invariably does. The appropriate institutional setting, which has clearly been achieved in Ngulula, cannot be taken for granted. ${ }^{4}$

There are other broader institutional constraints, particularly in relation to marketing. To the consternation of many locals, the supermarket Shoprite in Kasama does not procure locally, buying its vegetables from South Africa. Discussions between the Provincial Principal Secretary (PS) and Shoprite management indicated they would buy locally if the necessary quantity and quality could be assured, which it could not. A similar story occurred with the refugee camp near Mporokoso, which is largely supplied by imported foods such as beans. Cooperatives or marketing boards may be the answer, although the country's experience with these institutions has generally not been happy.

Finally, extension services are virtually nonexistent, despite an extension staff being located in Kasama, on account of lack of funds for travel. Trials are undertaken at the research station near the regional capital, but there is no means for diffusing knowledge to local farmers. Farmers in Lufubu value highly agricultural information and advice provided through radio programmes, especially those provided by the Ministry of Agriculture's community radio project Radio Farm Forum, that feature interviews with local, small-scale farmers talking through their farming plans and experiences.

Improvements to the supply-side need to be accompanied by some attention to the demand side. In principle, supply can bring its own demand as income rises (Say's Law). There is ample scope for increased consumption in Northern Province: many households eat only one meal a day during the lean season and eat meat only rarely. However, this "selfgenerating demand" is unlikely to be sufficient, especially if parallel efforts are not made to raise rural incomes. Possible activities to support demand include:

1. redressing imbalances in government and donor spending, so that a greater proportion takes place at grassroots level;

2. supporting systems for local procurement, e.g. donors financing a school feeding programme which uses locally purchased produce (which would also have nutritional benefits and increase school enrolments);

3. promotion of larger-scale investments, such as coffee and sugar plantations;

4. decentralisation of government activities, including locating some central functions in regional centres; and

5. payment for labour-intensive public works (which is contrary to current fashion for emphasising community contributions as a necessary indication of ownership). 


\section{Conclusions}

Zambia's economy has been in decline for three decades. This has macroeconomic aspects, but microlevel supply-side policies have done little to improve the fortunes of the majority; indeed the condition of many has worsened in the last decade. This deterioration stems from the end of input subsidies. Farmers are very clear on this point. While some households have diversified into new lines of production, these are a minority. The bulk of the 'agricultural turnaround', which is anyhow just offsetting the fall in maize production, has taken place among commercial farms. The exception has been the 5-10 per cent of rural households who have taken part in the expansion of cotton. Some other producers grow high-value crops for local markets, but the potential is limited given the sluggish nature of the economy. Many producers are also constrained by the poor quality of infrastructure. Those in more remote areas are thus caught in a poverty trap, whereby they cannot afford

\section{Notes}

* This article is based on field research financed by DFID. Further details of the project are available from www.ids.ac.uk/ids/pvty/pvrurallabour.html

1. DHS data accessed from www.measuredhs.com on 16 January 2005.

2. This system was not problem-free. It was plagued by growing inefficiencies, so that much maize went uncollected (Good 1986).

\section{References}

Good, K., 1986, 'Systematic agricultural mismanagement: the 1985 'bumper' harvest in Zambia', Journal of Modern African Studies, Vol 24: $257-84$

IDL Group, 2002, 'An assessment of trends in the Zambian agriculture sector', Report for DFID, Zambia: IDL Group, www.odi.org.uk/ FoodSecurity-Forum/docs/Zambia.pdf

Leavy, J., 2005, 'Social networks and market participation in Northern Province, Zambia', paper presented to workshop on 'Poverty and Rural Livelihoods in Zambia', Lusaka, March

Moore, H. and Vaughan, M., 1994, Cutting Down Trees, Portsmouth: Heinemann

Tschirley, D., Zulu, B. and Shaffer, J., 2004, 'Cotton in Zambia: an assessment of its organization, to purchase the inputs to increase output, and would lack markets even if they did. It is very doubtful that the market alone will improve the livelihoods of a large number of these households in the short to medium term. Supply-side measures (infrastructure, cooperative formation, etc.) need to be complemented by interventions that stimulate the demand side, such as public works and feeding programmes using locally procured produce.

The main lesson to draw from the Zambian experience is that every policy regime has both advantages and disadvantages. In discarding one policy regime in favour of another, care must be taken to ensure that the benefits of the old regime are not lost. In particular, institutions that were functioning well under the old regime should not be discarded until appropriate new institutions are put in place. The dismantling of the state institutions of agricultural distribution and marketing in the wake of liberalisation in Zambia left a huge lacuna that has not been adequately filled by the private sector to this day.

3. Out-grower schemes have two main advantages: (1) they are labour-intensive in comparison to large-scale commercial farming and (2) the farmers' marketing problems are solved.

4. Social networks relating to production and exchange in agriculture are explored in a companion article (Leavy 2005)

performance, current policy initiatives, and challenges for the future', Food Security Research Project Working Paper No 10, Lusaka: Food Security Research, www.aec.msu.edu/agecon/ fs $2 /$ zambia/index.htm

White, H., 1997, 'Zambia in the 1990s as a case of adjustment in Africa', African Development Review, Vol 9 No 2: 56-87

White, H. and Dijkstra, G., 2003, Program Aid and Development: Beyond Conditionality, London: Routledge

Zulu, B., Nijhoff, J.J., Jayne, T.S. and Negassa, A., 2000 , 'Is the glass half empty or half full? An analysis of agricultural production trends in Zambia', Food Security Research Project Working Paper No 3, Lusaka: Food Security Research www.aec.msu.edu/egecon/fs2/zambia/index.htm 